COMPARISON OF GLASGOW COMA SCALE (GCS) AND FULL OUTLINE OF UNRESPONSIVENESS (FOUR) TO ASSESS MORTALITY OF PATIENTS WITH HEAD INJURIES IN CRITICAL CARE AREA: A LITERATURE REVIEW

\title{
KOMPARASI GLASGOW COMA SCALE (GCS) DAN FULL OUTLINE OF UNRESPONSIVENESS (FOUR) UNTUK MENILAI MORTALITAS PADA PASIEN CEDERA KEPALA DI AREA PERAWATAN KRITIS: LITERATUR REVIEW
}

Nining Indrawati ${ }^{*}$, Christin Novita Kupa ${ }^{2}$, Era Marthanti Putri ${ }^{3}$, Lona Lorenza Lesimanuaya ${ }^{4}$, Veronica Evi Alviolita ${ }^{5}$, Viky Septiani ${ }^{6}$

\begin{abstract}
Background: A head injury is a critical illness that requires specific treatments in the intermediate care room at the hospital. A head-injured patient may experience changes in his condition, namely decreased consciousness. Decreased consciousness will affect the prognosis and mortality of patients, in case in critical care areas, the appropriate measurement scale is needed, such as Glasgow Coma Scale (GCS) and Full Outline of UnResponsiveness (FOUR) to assess the level of consciousness. Objective: Cmparing the level of consciousness measurement using GCS and FOUR to assess mortality in head injured patients in critical care areas. Methods: The study was conducted by reviewing eleven journals from Portal Garuda, EBSCO, PROQUEST, CANGAGE and DOAJ published from 2010 to 2020. Results: GCS and FOUR can be used in predicting mortality of head-injured patients in critical care wards. FOUR is an accurate predictor of survival by assessing fungtional status and signs of nonverbal awareness by assessing visual pursuits. Conclusion: GCS and FOUR are effective measuring instruments to assess mortality in head-injured patients, however it is more appropriate to use FOUR for patients with intubation.
\end{abstract}

Keywords: Brain Injury, GCS, Mortality

INTISARI

Latar Belakang: Cedera kepala merupakan penyakit kritis yang membutuhkan perawatan khusus di ruang intermediate care di Rumah Sakit. Pasien cedera kepala bisa mengalami perubahan kondisi yaitu penurunan kesadaran. Perubahan kondisi ini akan mempengaruhi prognosis dan mortalitas pasien, sehingga pada area perawatan kritis membutuhkan skala pengukuran yang tepat diantaranya Glasgow Coma Scale (GCS) dan Full Outline of UnResponsiveness (FOUR) untuk menilai tingkat kesadaran. Tujuan: Membandingkan pengukuran tingkat kesadaran menggunakan GCS dan FOUR untuk menilai mortalitas pada pasien cedera kepala di area perawatan kritis.

Afiliasi Penulis

STIKES Bethesda Yakkum Yogyakarta

Korespondensi kepada

Nining Indrawati

nining@stikesbethesda.ac.id
Metode: Penelitian dilakukan dengan metode literature review dengan menelaah sebelas jurnal dari Portal Garuda, EBSCO, PROQUEST, CANGAGE dan DOAJ yang dipublikasikan dari tahun 2010 sampai dengan tahun 2020. Hasil: GCS 
dan FOUR dapat digunakan dalam memprediksi mortalitas pasien cedera kepala di ruang perawatan kritis. FOUR merupakan prediktor akurat dalam menentukan kelangsungan hidup pasien dengan menilai status fungsional dan tanda-tanda kesadaran nonverbal dengan menilai pengejaran visual. Kesimpulan: GCS dan FOUR merupakan alat ukur yang efektif untuk menilai mortalitas pada pasien cedera kepala, tetapi pada pasien dengan intubasi akan lebih tepat menggunakan FOUR.

Kata Kunci: Cedera Kepala, GCS, Mortalitas

\section{PENDAHULUAN}

Cedera kepala adalah serangkaian kejadian patofisiologik yang terjadi setelah trauma kepala, yang dapat melibatkan setiap komponen yang ada, mulai dari kulit kepala, tulang dan jaringan otak atau kombinasinya (Price dan Wilson, 2012). Cedera kepala akibat trauma sering kita jumpai di lapangan. Di dunia kejadian cedera kepala setiap tahunnya diperkirakan mencapai 500.000 kasus dari jumlah di atas $10 \%$ penderita meninggal sebelum tiba di rumah sakit dan lebih dari 100.000 penderita menderita berbagai tingkat kecacatan akibat cedera kepala tersebut (Depkes, 2012). WHO mencatat 2500 kasus kematian yang disebabkan karena kecelakaan lalu lintas pada tahun 2013. Tahun 2014 di Amerika Serikat cedera kepala yang diakibatkan oleh kejadian jatuh yang tidak disengaja memiliki prevalensi tertinggi yaitu $52,3 \%$, sedangkan cedera kepala yang diakibatkan oleh kecelakaan kendaraan bermotor memiliki prevalensi $20,4 \%$ dari total keseluruhan pasien rawat inap dengan diagnosa cedera kepala (Peterson dkk., 2019). Di Indonesia, kejadian cedera kepala mencapai 11,9\% sedangkan di DI Yogyakarta mencapai 11\% dari total proporsi bagian tubuh yang cedera (Riskesdas, 2018).

Cedera kepala secara langsung atau tidak langsung yang mengenai kepala dapat mengakibatkan luka di kulit kepala, fraktur tulang tengkorak, robekan selaput otak, dan kerusakan jaringan otak itu sendiri, serta mengakibatkan gangguan neurologis yang dapat menyebabkan penurunan kesadaran (Sjahrir, 2012). Secara umum cedera kepala diklasifikasifan menurut skala Glasgow Coma Scale (GCS) dikelompokkan menjadi tiga : (1) Cedera Kepala Ringan (GCS 13-15) dapat terjadinya kehilangan kesadaran atau amnesia selama kurang dari 30 menit, tidak ada kontusio tengkorak, tidak adanya fraktur serebral, hematoma (2) Cedera Kepala Sedang (GCS 9-12) hilangnya kesadaran dan atau amnesia lebih dari 30 menit namun kurang dari waktu 24 jam, bisa mengalami terjadinya fraktur tengkorak, (3) Cedera Kepala Berat (GCS 3-8) dapat kehilangan kesadaran dan atau terjadi amnesia apabila lebih dari 24 jam meliputi kontusio serebral, laserasi, atau hematoma intrakranial (Amien dan Hardhi, 2016).

Cedera kepala merupakan penyakit kritis yang membutuhkan perawatanperawatan khusus yang biasanya dirawat dalam ruang perawatan kritis atau ruang Intermedite Care (IMC) di Rumah Sakit. Kondisi cedera kepala bisa mengalami perubahan seperti, terlihat linglung (padangan kosong), pusing, kehilangan keseimbangan, mual atau muntah, mudah merasa lelah, mudah mengantuk, penglihatan kabur, telinga bedenging, penurunan sensitifitas pada semua indra. Perubahan kondisi ini akan mempengaruhi prognosis. Menurut Priguna (Nasution, 2014) prognosis akan lebih baik bila penatalaksanaannya dilakukan secara tepat dan cepat, sehingga pada area perawatan kritis membutuhkan skala pengukuran yang tepat untuk menilai tingkat 
kesadaran diantaranya dapat menggunakan skala ukur Glasgow Coma Scale (GCS) dan Full Outline of UnResponsiveness (FOUR). GCS merupakan alat untuk mengukur tingkat kesadaran pada pasien cedera kepala dengan melibatkan 3 komponen yaitu respon mata, respon verbal dan respon motorik dengan skor total terdiri atas 15 poin. FOUR merupakan skala koma baru yang terdiri atas 4 komponen (respons mata, respons motorik, refleks batang otak dan pola pernafasan), dengan skor total terdiri atas 17 poin (mulai dari 0-16). Skor FOUR diasumsikan lebih superior dibanding terhadap GCS, karena dapat diaplikasikan untuk pasien dengan intubasi dan menilai lock-in syndrome dan mendeteksi vegetative state (Wijdicks 2005 dalam Tua, 2014).

Hasil riset yang dilakukan oleh Ghelichkhani, P., Esmaeili, M., Hosseini, M., \& Seylani, K. (2018), bahwa evaluasi yang dilakukan pada pasien cedera kepala dengan menggunakan skala ukur GCS dan FOUR pada pasien saat masuk, 6 jam, 12 jam, dan 24 jam setelah masuk menunjukkan bahwa mean dan standar deviasi kedua skala ukur ini berbeda antara mereka yang meninggal dan mereka yang bertahan dalam 4 titik yang dievaluasi. Penelitian yang lain oleh Jalali, R., \& Rezaei, M. (2014) yang membandingkan antara skala ukur GCS dan FOUR, menunjukkan bahwa skala ukur FOUR memiliki prediksi yang lebih baik dalam menilai gangguan kesadaran karena FOUR tidak hanya menilai respon verbal saja pada pasien, namun memberikan informasi detail tentang status neurologis dengan memasukkan reflek batang otak dan pola pernapasan pada komponen yang dinilai.

Hasil wawancara kepada beberapa perawat yang ada di Rumah Sakit seringkali perawat hanya menggunakan alat ukur GCS untuk menilai tingkat kesadaran, namun belum pernah mendapatkan informasi tentang penggunaan FOUR sebagai alat ukur tingkat kesadaran. Penting bagi perawat untuk mengetahui penggunaan antara alat ukur GCS dan FOUR. Untuk itu, pada penelitian ini berfokus untuk melihat perbandingan penggunaan alat ukur GCS dan FOUR dalam menilai mortalitas pada pasien dengan cedera kepala.

\section{METODOLOGI}

Metode yang digunakan adalah tinjauan literatur. Pencarian artikel berbasis komputer menggunakan Portal Garuda, EBSCO, PROQUEST, CANGAGE dan DOAJ. Pencarian artikel menggunakan kata kunci yang meliputi GCS, FOUR, Brain Injury, prognosis, mortality, tingkat kesadaran (level of consciousness), intensive care, trauma kepala yang dipublikasikan dari tahun 2010 sampai dengan 2020. Peneliti mendapatkan 100 artikel yang kemudian dipilih sesuai inklusinya sehingga mendapatkan 11 artikel yang sesuai. Kriteria inklusi dalam penelitian ini yaitu subyek penelitian merupakan pasien yang dilakukan di perawatan kritis, menyebutkan penilaian GCS dan FOUR dalam prediksi prognosis, mortalitas pasien cedera kepala dan penelitian dalam bahasa Indonesia atau Inggris. Sedangkan kriteria eksklusinya adalah artikel yang tidak merupakan full text. 


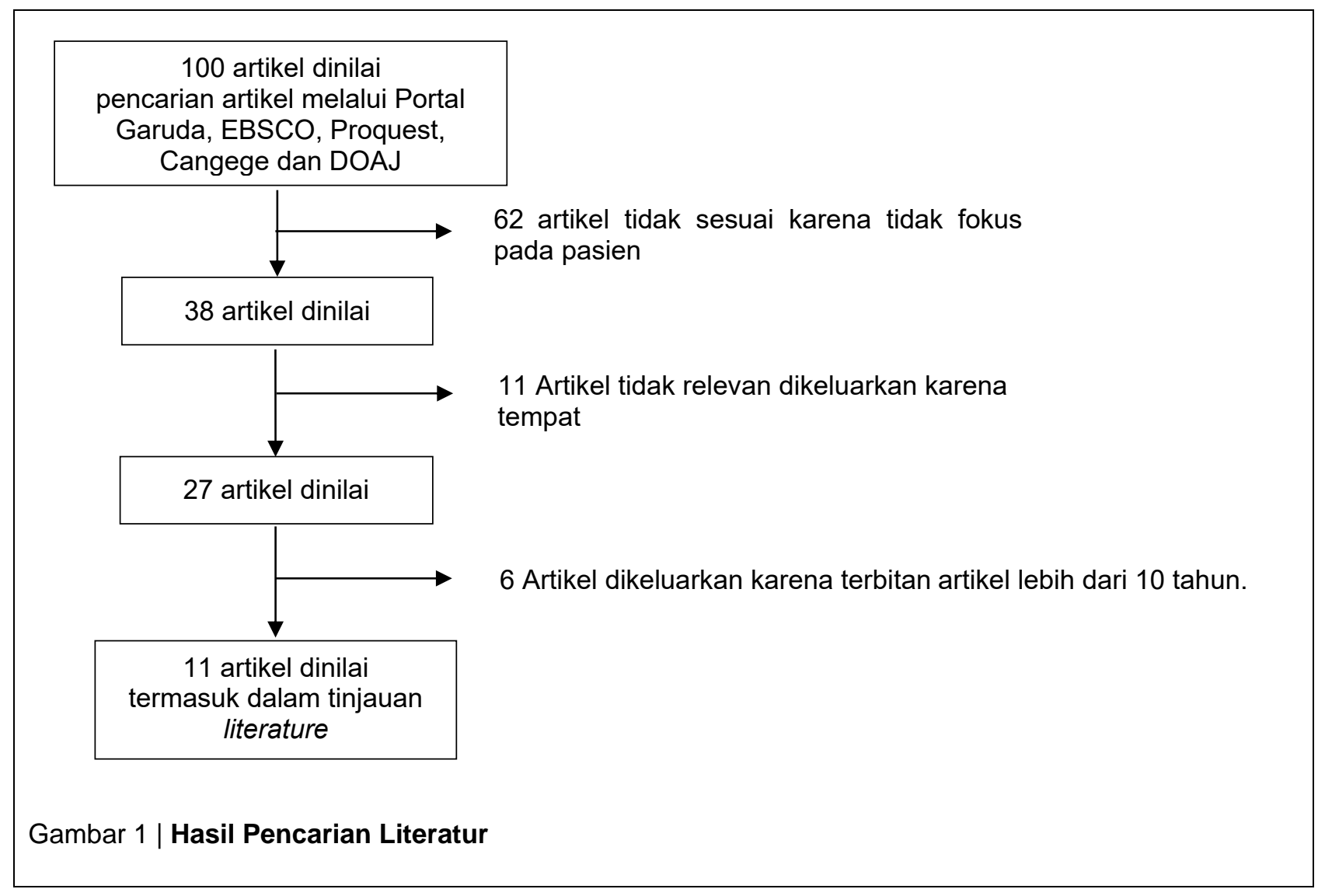

\section{HASIL DAN PEMBAHASAN}

Hasil dari penelusuran dari database EBSCO, Portal Garuda Proquest, Cangege dan DOAJ diperoleh 11 artikel yang relevan yang memberikan informasi tentang GCS dan FOUR dalam memprediksi mortalitas pada pasien cedera kepala. Desain penelitian empat dari sebelas jurnal diantaranya menggunakan metode penelitian observasional, tiga jurnal menggunakan metode penelitian studi akurasi diagnostik prospektif, satu jurnal menggunakan metode penelitian studi kohort prospektif, satu jurnal menggunakan metode penelitian studi prospektif, satu jurnal menggunakan metode penelitian studi deskriptif, dan satu jurnal menggunakan metode penelitian review artikel.

Tabel 1 | Komparasi GCS dan FOUR

\begin{tabular}{lll}
\hline \multicolumn{1}{c}{ Komparasi } & \multicolumn{1}{c}{ GCS } & \multicolumn{1}{c}{ FOUR } \\
\hline Uji Reliabilitas & \multicolumn{1}{c}{0,888} & 0,973 \\
\hline $\begin{array}{l}\text { Pengaruh terhadap } \\
\text { mortalitas pasien cedera } \\
\text { kepala }\end{array}$ & $\begin{array}{l}\text { Setiap kenaikan skor pada } \\
\text { GCS dapat menghasilkan } \\
\text { penurunan peluang kematian }\end{array}$ & $\begin{array}{l}\text { Setiap kenaikan skor pada } \\
\text { FOUR dapat menghasilkan } \\
\text { penurunan peluang kematian }\end{array}$ \\
\hline $\begin{array}{l}\text { Outcome pasien cedera } \\
\text { kepala }\end{array}$ & $\begin{array}{l}\text { GCS dapat menentukan } \\
\text { kelangsungan hidup pasien }\end{array}$ & $\begin{array}{l}\text { Prediktor akurat menentukan } \\
\text { kelangsungan hidup pasien } \\
\text { (status fungsional dan hasil }\end{array}$ \\
\hline
\end{tabular}




\begin{tabular}{lll}
\hline Komparasi & GCS & \multicolumn{1}{c}{ FOUR } \\
\hline & $\begin{array}{l}\text { kognitif) berdasarkan reflek } \\
\text { batang otak }\end{array}$ \\
\hline
\end{tabular}

Satu jurnal membahas reliabilitas antara Skor FOUR dan GCS dimana persepsi antar observer dalam menilai tingkat kesadaran dengan menggunakan GCS dan FOUR adalah sama. Hasil reliabilitas GCS dan FOUR menunjukkan bahwa nilai reliabilitas GCS dan FOUR memiliki nilai yang baik sampai dengan sangat baik sehingga alat ukur GCS dan FOUR dapat digunakan pada pasien kritis (Untung, Ika, dan Hery, 2017). Satu jurnal membahas tentang skor GCS yang mengatakan Skala Koma Glasgow adalah skala yang paling umum digunakan pada pasien trauma kepala. Dari komponen E V M komponen $M$ adalah yang terpenting (Agrawal, 2018).

Dua jurnal membahas tentang skor FOUR dan GCS terhadap mortalitas. Kedua jurnal ini membahas GCS dan FOUR dalam memprediksi kematian dan kelangsungan hidup pasien setelah keluar dari rumah sakit dan hasilnya kedua alat ukur tersebut memiliki nilai yang sama dalam memprediksi kematian (Parisa, Maryam, Mostafa, Khatereh, 2018; Amir, Barth, Davis, Abdirahim, Nan, Richard, Stephen, Cumara, 2020). Tujuh jurnal membahas tentang outcome pasien cedera kepala. Ketujuh jurnal tersebut mengatakan FOUR merupakan prediktor akurat dalam menentukan kelangsungan hidup pasien seperti menilai status fungsional dan hasil kognitif dan dapat mengidentifikasi tandatanda kesadaran non-verbal dengan menilai pengejaran visual. FOUR skor juga mampu memprediksi kondisi pasien berdasarkan tingkat mortalitas, kondisi outcome yang buruk seperti mendeteksi kematian otak pada pasien sakit kritis (Bruno dkk, 2011).

Kesadaran merupakan suatu kondisi dimana seseorang mampu mengenal tentang dirinya dan berespon terhadap stimulus yang diberikan dilingkungan dari lingkungan (Morton dan Fontaine, 2012). Penilaian tingkat kesadaran merupakan salah satu kemampuan dasar yang harus dimiliki perawat. Penilaian tingkat kesadaran merupakan indikator penting dalam menentukan prognosis pasien (Dewi dkk, 2011). Skala koma yang ideal seharusnya bersifat linear (mempunyai bobot yang sama bagi setiap komponen), reliable (mengukur yang seharusnya diukur), valid (menghasilkan nilai yang sama pada pemeriksaan berulang) dan mudah digunakan (memiliki instruksi yang sederhana tanpa memerlukan alat bantu atau kartu). Terdapat berbagai alat ukur untuk penilaian kesadaran, namun belum secara pasti keakuratannya untuk dapat diterapkan pada pasien (Rismala, 2016).

Cedera kepala sering kali membuat pasien mengalami penurunan kesadaran, karena cedera kepala biasanya disebabkan oleh trauma pada kepala dan dapat mengakibatkan pendarahan serta pembengkakan otak yang meningkatkan tekanan. Peningkatan tekanan di dalam kepala tersebut menyebabkan otak terdesak sehingga saraf-saraf di dalamnya rusak dan mengalami gangguan. Otak yang mengalami gangguan mempengaruhi impuls yang menuju Sistem saraf pusat, sehingga masukan impuls dari pusat sensorik pada korteks serebri menuju ARAS (Ascending reticular activating system) tertanggu, kemudian diproyeksikan kembali ke korteks cerebri sehingga akan mempengaruhi aktivitas korteks dan kesadaran (Price, 2012). Ketepatan dalam menentukan kesadaran pasien sangat penting untuk menentukan prognosis dan outcome pasien. 
Pengukuran tingkat kesadaran dapat menggunakan alat ukur GCS ataupun FOUR. Skala ukur GCS merupakan skala ukur penilaian tingkat kesadaran yang umumnya digunakan. GCS mengandung tiga komponen yaitu pergerakan mata, verbal, dan pergerakan motorik yang dinilai dengan memberikan skor pada masing-masing komponen. Pada pasien cedera otak dapat di klasifikasikan sebagai ringan (skor GCS 1415), sedang (skor GCS 9-13), dan berat (skor GCS $\leq$ 8) (Kirkham, 2008; Rismala, 2016). Selain itu mudah dilakukan, GCS juga memiliki peranan penting dalam memprediksi resiko kematian diawal pemeriksaan, akan tetapi GCS memiliki kelemahan dalam penilaian komponen verbal pada pasien terintubasi (Oktarina 2017). Selain itu, kelemahan lain yang dimiliki oleh skala ukur GCS yaitu tidak mengkaji refleks batang otak dan respirasi, padahal obat-obatan sedasi yang biasa digunakan akan mempengaruh kemampuan pasien dalam membuka mata dan respon motorik. Akan tetapi, penggunaan obat sedasi tidak akan mempengaruhi reflex batang otak dan respirasi pasien (Oktarina, 2017). Glasgow Coma Scale tetap menjadi metode paling umum digunakan untuk menilai tingkat kesadaran pada pasien cedera otak traumatis dikarenakan GCS merupakan instrumen standar yang lebih aplikatif digunakan, namun pengkajian tingkat kesadaran dengan menggunakan GCS sulit untuk dilakukan untuk menilai respon verbal pada pasien terintubasi, tidak bisa untuk mengetahui reflek batang otak dan perubahan pola nafas.

Berbeda dengan GCS, skala ukur FOUR tidak hanya memberikan penilaian pada komponen mata dan respon motorik tetapi juga pada reflek batang otak. FOUR dapat membantu dalam penilaian kedalaman koma yang lebih lengkap dan akurat seperti reflek cahaya pupil, reflek kornea dan reflek batuk.
FOUR dapat menilai fungsi mesensefakon, pons, medulla oblongata dan saraf okulomotor, penilaian mata, respon motorik dengan spektrum luas, pola nafas abnormal yang dapat mencerminkan adanya disfungsi bihemisfer atau batang otak bagian bawah yang mengendalikan pernapasan dan berhubungan dengan prognosis buruk. Pada pasien yang terintubasi, jumlah frekuensi napas yang melebihi frekuensi yang diberikan oleh mesin menggambarkan masih adanya fungsi pusat pernapasan atau usaha bernapas, serta usaha nafas pada pasien yang memakai ventilator dengan skala penilaian 0-4 setiap komponen (Khajeh, 2014). FOUR skor dianggap lebih baik dibandingkan dengan skala-skala yang telah ada sebelumnya dalam mengklasifikasikan penurunan kesadaran. FOUR skor lebih sederhana dan memberikan informasi yang lebih baik, terutama pada pasien-pasien yang terintubasi. Skala ini dapat membantu klinisi untuk bertindak lebih cepat atas perubahan klinis pasien dan memudahkan dalam pertukaran informasi yang lebih akurat dengan klinisi lain (Khajeh, 2014). Kelebihan lain dari FOUR skor adalah tetap dapat digunakan pada pasien-pasien dengan gangguan metabolik akut, syok atau kerusakan otak nonstruktural lain karena skala ini dapat mendeteksi perubahan kesadaran lebih dini (Dewi, 2016). Instrumen FOUR skor, semua item penilaian dapat dilakukan pada pasien yang terintubasi ataupun tidak, bahkan skala ini dapat digunakan untuk menilai status vegetatif dan pasien locked syndrome (Dewi, 2016).

Nilai pada setiap komponen dalam instrumen GCS memiliki nilai yang berbeda, sedangkan pada FOUR mempunyai nilai yang sama pada setiap komponennya (Agrawal, 2018 dan Sujianto dkk., 2017). Penelitian Ghelichkani dkk (2018), menyatakan bahwa dari 90 orang pasien cedera kepala yang 
berasal dari dua rumah sakit yang berbeda dan dilakukan penilaian dengan menggunakan skala GCS dan FOUR untuk memprediksi mortalitas mulai dari masuk perawatan, 6 jam, 12 jam, dan 24 jam perawatan, hasil perbandingan kedua alat ukur tersebut bahwa nilai dari skor GCS dan FOUR tidak menunjukkan nilai yang berbeda setiap jamnya. Hasil ini menunjukkan bahwa keduanya memiliki nilai prediksi yang sama dalam mengidentifikasi tingkat kesadaran pada pasien cedera kepala. Penelitian Abdallah dkk (2019), menyatakan bahwa skor GCS dan FOUR dapat memprediksi kematian dalam 30 hari karena mampu menilai mortalitas pada pasien di unit gawat darurat rumah sakit.

Penilaian antara GCS dan FOUR terhadap outcome pada pasien cedera kepala didapatkan FOUR lebih spesifik dalam menilai prognosis pasien. FOUR menunjukkan beberapa nilai positif atau kelebihan untuk melengkapi hasil penilaian yang tidak ada atau tidak terkaji jika menggunakan GCS. Keunggulan alat ukur FOUR yaitu memiliki skor komponen yang sama setiap item (E4 M4 B4 R4) sehingga mudah diingat jika dibandingkan dengan GCS (E4 V5 M6). Alat ukur FOUR tidak menilai verbal karena pada umumnya pasien dengan perawatan intensif sebagian besar dalam keadaan kritis yang telah menjalani intubasi sehingga tidak dapat menunjukkan respon verbal. Selain itu FOUR dapat menilai respon batang otak dan pernafasan sehingga lebih akurat dalam memprediksi kematian pasien dengan cedera otak. Komponen reflek batang otak merupakan komponen yang memiliki tingkat akurasi dan menilai penuh pada pasien dengan keadaan koma (Tua, 2014). Sejalan dengan penelitian Sharath dkk (2017) yang mengatakan FOUR berbeda dengan GCS yaitu tidak mengamati respon verbal karena pada pasien kritis tidak menunjukkan respon verbal tetapi lebih menilai respon mata maupun gerakan yang merupakan salah satu tanda pertama terjadinya pemulihan kesadaran. Menurut Gorji, Hoseini, Gholipur dan Mohammadpur (2014) mengatakan bahwa FOUR dapat digunakan pada pasien 24 jam pertama saat masuk rumah sakit dan dapat mengevaluasi pasien intubasi dan dapat mendiagnosis locking syndrome. Menurut Duncan, Aldstadt, Whalen, Melly dan Gortmaker (2011) mengatakan FOUR skor sangat aplikatif dan berguna untuk pasien dengan gangguan metabolik akut, sepsis atau syok, cedera kepala nonstruktural lainnya, karena dapat mendeteksi perubahan awal dalam tingkat kesadaran, misalnya ketidakmampuan untuk mengikuti perintah, ketidakmampuan untuk melakukan gerakan dan muncul pernapasan Cheyne-Stokes.

\section{KESIMPULAN}

GCS dan FOUR merupakan alat ukur yang efektif dalam menilai prognosis dan mortalitas pada pasien cedera kepala. GCS menjadi metode yang paling umum digunakan untuk menilai tingkat kesadaran, tetapi jika mengukur tingkat kesadaran pada pasien cedera kepala dengan intubasi akan lebih tepat jika menggunakan alat ukur FOUR.

\section{DAFTAR PUSTAKA}

Abdallah, A., Demaerschalk, B. M., Kimweri, D., Aden, A. A., Zhang, N., Butterfield, R., \& Carroll, C. B. (2019). A comparison of the Full Outline of Unresponsiveness (FOUR) and Glasgow Coma Scale (GCS) Scores in Predicting Mortality Among Patients with Reduced Level of Consciousness in Uganda. Neurocritical care, 1-8. https://doi.org/10.1007/s12028-01900806-4 
Amin, H. dan Hardhi, K. (2016). Asuhan Keperawatan Praktis, Berdasarkan Penerapan Diagnosa, Nanda, NIC, NOC dalam Berbagai Kasus. Edisi Revisi Jilid 1. Yogyakarta: MediAction

Bruno, M. A., Ledoux, D., Lambermont, B., Damas, F., Schnakers, C., Vanhaudenhuyse, A., ... \& Laureys, S. (2011). Comparison of the Full Outline of UnResponsiveness and Glasgow Liege Scale/Glasgow Coma Scale in an intensive care unit population. Neurocritical care, 15(3), 447-453.

Depkes RI. (2012). Laporan Hasil Riset Kesehatan Dasar Indonesia. Jakarta: Badan Penelitian dan Pengembangan Kesehatan Depkes RI.

Depkes RI. (2015). Laporan Hasil Riset Kesehatan Dasar Indonesia. Jakarta: Badan Penelitian dan Pengembangan Kesehatan Depkes RI.

Depkes RI. (2018). Laporan Hasil Riset Kesehatan Dasar Indonesia. Jakarta: Badan Penelitian dan Pengembangan Kesehatan Depkes RI.

Ghelichkhani, P., Esmaeili, M., Hosseini, M., \& Seylani, K. (2018). Glasgow Coma Scale and FOUR Score in predicting the mortality of trauma patients; a diagnostic accuracy study. Emergency, 6(1).

Gorji, M. A. H., Hoseini, S. H., Gholipur, A., \& Mohammadpur, R. A. (2014). A comparison of the diagnostic power of the Full Outline of Unresponsiveness scale and the Glasgow coma scale in the discharge outcome prediction of patients with traumatic brain injury admitted to the intensive care unit. Saudi Journal of Anaesthesia, 8(2), 193.

Jalali, R., \& Rezaei, M. (2014). A comparison of the Glasgow Coma Scale score with full outline of unresponsiveness scale to predict patients' traumatic brain injury outcomes in intensive care units. Critical care research and practice, 2014.

Khajeh, A., Fayyazi, A., Miri, G., Askari, K., dan Noori, N.. (2014). Comparison Between The Ability Of GCS and FOUR to Predict The Mortality and Disharge Rate Of Pediatric ICU. Iran

McNett, M., Amato, S., Gianakis, A., Grimm, D., Philippbar, S. A., Belle, J., \& Moran, C. (2014). The FOUR score and GCS as predictors of outcome after traumatic brain injury. Neurocritical care, 21(1), 52-57.

Nair, S. S., Surendran, A., Prabhakar, R. B., \& Chisthi, M. M. (2017). Comparison between FOUR score and GCS in assessing patients with traumatic head injury: a tertiary centre study. International Surgery Journal, 4(2), 656-662

Nasution, S. (2014). Mild Head Injury. Medula. 2(4), 89-96

Oktarina, Y., dan Simanjuntak, A. (2017). Perbandingan GCS dengan FOUR dalam Mengukur Tingkat Kesadaran Pada Pasien Terintubasi Endotrachea Di ICU. Jambi : Universitas Jambi. http://conference.unsri.ac.id/index.php/S NK/article/download/747/377. Diakses pada Oktober 2020 
Peterson, A. B., Xu, L., Daugherty, J., \& Breiding, M. J. (2019). Surveillance report of traumatic brain injury-related emergency department visits, hospitalizations, and deaths, United States, 2014.

Price S., \& Wilson, L. (2012). Patofisiologi: Konsep Klinis Proses-Proses Penyakit. Jakarta: EGC.

Rismala, D. (2016). Tinjauan Pustaka Penilaian Kesadaran pada Anak Sakit Kritis: GCS atau FOUR. Jakarta : Departemen IImu Kesehatan Anak Fakultas Kedokteran Universitas Indonesia.

Sahin, A. S., Sahin, M., Ozturk, N. K., Kızılates, E., \& Karslı, B. (2015). Comparision Of GCS And FOUR Scores Used In The Evaluation Of Neurological Status In Intensive Care Units Yogun Bakım Unitelerinde Norolojik Durumun Degerlendirilmesinde Kullanılan GKS ve FOUR Skorlarının

Karsılastırılması. Journal

of Contemporary Medicine, 5(3).

Sujianto, U., Silvitasari, I., \& Purnomo, H. D. (2017). Reliabilitas Instrumen GCS Dan FOUR Score Untuk Menilai Tingkat Kesadaran Pasien Di Ruang ICU 2017. Adi Husada Nursing Journal, 3(1), 23-27. Retrieved from https://adihusada.ac.id/jurnal/index.php/ AHNJ/article/view/72

Tua, M. (2014). Perbandingan Ketepatan Prediksi Mortalitas Pasien Cedera Kepala Berdasarkan Skor FOUR (Full Outline Of Unresponsiveness) Dan SKG (Skala Koma Glasgow). Diakses tanggal 15 september 2020.
Waladani, B., dan Ning I. (2018). Pengkajian Pasien Menggunakan FOUR Score Coma SCALE Di Ruang Perawatan Intensive Care Unit (ICU). http://ejournal.stikesmuhgombong.ac.id/i ndex.php/JIKK/index. Diakses pada tanggal 21 September 2020 